\title{
Noncoding RNAs of the H/ACA Family
}

\author{
M. TERnS AND R. TERnS \\ Departments of Biochemistry and Molecular Biology, and Genetics, University of Georgia, \\ Athens Georgia 30602
}

\begin{abstract}
The H/ACA RNAs are an abundant family of trans-acting, noncoding RNAs found in eukaryotes and archaea. More than 100 H/ACA RNAs are known to exist in humans. The function of the majority of the identified H/ACA RNAs is to guide sitespecific pseudouridylation of ribosomal RNA. In eukaryotes, H/ACA RNAs also mediate the processing of pre-rRNA, provide the template for telomere synthesis, and guide pseudouridylation of other classes of target RNAs (e.g., small nuclear RNAs [snRNAs]). Thus, currently, the H/ACA RNAs are known to be integrally involved in the production of both ribosomes and spliceosomes, and in the maintenance of chromosome integrity. In addition, dozens of H/ACA RNAs have been identified for which no function has yet been determined. The H/ACA RNAs select and present substrate molecules via basepairing. All H/ACA RNAs contain conserved sequence elements (box H and box ACA) and assemble with a core set of four proteins to form functional ribonucleoprotein complexes (RNPs). Mutations in key RNA and protein components of H/ACA RNPs result in dyskeratosis congenita, a serious multisystem genetic disease. Impressive progress has been made very recently in understanding the biogenesis, trafficking, and function of H/ACA RNPs.
\end{abstract}

\section{FUNCTIONAL DIVERSITY OF H/ACA RNPS}

The H/ACA RNAs are one of the largest classes of noncoding RNAs (second only perhaps to microRNAs), with numbers of unique H/ACA RNA species exceeding 100 in mammals and plants (Brown et al. 2003; Kiss et al. 2004; Lestrade and Weber 2006). H/ACA RNAs are present in all eukaryotes and archaea, but not apparently in bacteria, and have evolved to provide a remarkably diverse set of functions. Protein translation, pre-mRNA splicing, and genome stability depend on the function of H/ACA RNAs in eukaryotes (Kiss 2002; Terns and Terns 2002; Meier 2005; Yu et al. 2005). H/ACA RNAs involved in different functions are adapted to interact with various sets of partner proteins. The H/ACA RNAs all assemble with a core set of proteins to form metabolically stable H/ACA RNA-protein complexes (RNPs). For the majority (i.e., the RNAs involved in RNA pseudouridylation), these four core proteins and the H/ACA RNA comprise a complete functional unit (Baker et al. 2005; Charpentier et al. 2005). In other cases (e.g., RNAs involved in RNA processing and telomere synthesis), additional proteins are required to make a catalytically active complex (Lubben et al. 1995; Autexier and Lue 2006). Although a catalytic role for some H/ACA RNAs has not been excluded, in the known instances, catalytic activity resides in one of the partner proteins.

H/ACA RNPs act in trans on multiple cellular targets to influence major cellular processes (Fig. 1). The targets are usually other cellular RNAs - rRNAs and snRNAsbut at least one DNA substrate- the vertebrate telomere-is also known. H/ACA RNAs recognize substrates by base-pairing. The H/ACA RNPs function at a variety of distinct sites, all within the nucleus, where their substrates are found. Established sites of action include nucleoli (rRNA substrates), Cajal bodies (snRNA substrates), and chromosome ends (telomere substrates).

\section{Small Nucleolar RNPs and Ribosome Biogenesis}

By far, the vast majority of H/ACA RNPs participate in ribosome biogenesis in the nucleolus and thus are called small nucleolar RNPs (snoRNPs) (or simply sRNPs in the anucleate archaea) (Fig. 1). The H/ACA snoRNPs contribute to ribosome production via at least two distinct mechanisms. The RNAs interact with specific regions of pre-rRNA and guide either site-specific nucleotide modification (conversion of uridines to pseudouridines) or endoribonucleolytic cleavage. Most H/ACA RNPs catalyze

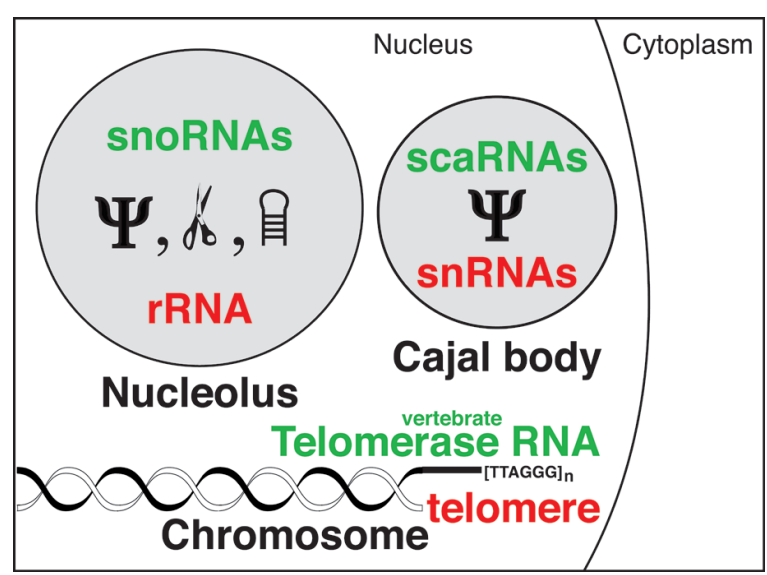

Figure 1. The molecular targets, functions, and sites of action of eukaryotic H/ACA RNAs. Distinct classes of H/ACA RNAs (green) act on target molecules (red) found in various nuclear compartments. The snoRNAs are essential for pseudouridylation $(\Psi)$, processing (scissors), and folding (hairpin) of rRNAs transcribed within the nucleolus. scaRNAs localize to Cajal bodies to guide the pseudouridylation of snRNAs. Telomerase RNA moves to chromosome ends during $\mathrm{S}$ phase where it functions to guide and template telomere synthesis $\left(\mathrm{TTAGGG}_{n}\right)$. 
rRNA pseudouridylation, producing more than 100 modifications in humans (Maden 1990). Pseudouridylation is also presumably the ancestral function, as it is common to both eukaryotes and archaea. In eukaryotes, a few H/ACA snoRNPs (U17/snR30, snR10, and perhaps E2 and E3) are required for pre-rRNA processing (Tollervey 1987; Morrissey and Tollervey 1993; Mishra and Eliceiri 1997; Atzorn et al. 2004). The processing snoRNPs are essential for the generation of mature rRNA species (e.g., 28S, $5.8 \mathrm{~S}$, and $18 \mathrm{~S}$ rRNAs of vertebrates) and cell viability.

Precisely how targeted pseudouridylation of pre-rRNA aids in the assembly of active ribosomes is not yet clear. The occurrence of pseudouridine in diverse classes of noncoding RNAs (rRNA, tRNA, snRNA, and snoRNAs) and not mRNAs suggests that the modification has a role in structured RNAs. Moreover, the fact that the pseudouridines cluster to functionally important domains of the large and small rRNAs (e.g., peptidyl transferase and decoding centers) strongly implicates the modification in ribosome function (Ofengand et al. 2001; Decatur and Fournier 2003; King et al. 2003; Yu et al. 2005). It is anticipated that transient, site-specific base-pairing of H/ACA RNAs to nascent pre-rRNA molecules also contributes to productive rRNA folding (i.e., RNA chaperoning) (Bachellerie et al. 1995; Steitz and Tycowski 1995). Individually, no H/ACA pseudouridylation guide RNA has been found to be essential for cell viability. However, loss of more than one (or global loss of) pseudouridine is lethal (Decatur and Fournier 2003; Yu et al. 2005).

\section{Small Cajal Body RNPs and Pre-mRNA Splicing}

In eukaryotes, some H/ACA RNAs guide pseudouridylation of snRNAs (e.g., U1, U2, U4, and U5) that function in pre-mRNA splicing (Fig. 1) (Darzacq et al. 2002; Kiss et al. 2002; Richard et al. 2003). This relatively newly discovered class of H/ACA RNPs functions in Cajal bodies, conserved nuclear structures that appear to be important centers for a variety of RNP assembly and RNA modification reactions (Gall 2000; Cioce and Lamond 2005; Matera and Shpargel 2006). Accordingly, this class of pseudouridylation guide H/ACA RNPs are called the small Cajal body RNPs (scaRNPs) (Darzacq et al. 2002). In some cases, pseudouridylation of spliceosomal snRNAs by scaRNPs has been shown to be essential for snRNP function and pre-mRNA splicing (Yu et al. 2005).

\section{Vertebrate Telomerase and Genome Stability}

Telomerase, the enzyme that adds telomeric DNA repeats to the ends of linear chromosomes in eukaryotic cells (Greider and Blackburn 1985), is required to maintain telomere length and prevent genome instability (de Lange 2005; Hug and Lingner 2006). Vertebrate telomerase is a specialized H/ACA RNP (Fig. 1). The enzyme includes telomerase RNA (an adapted H/ACA RNA) and the four core H/ACA RNP proteins plus telomerase reverse transcriptase (TERT) (Mitchell et al. 1999b; Chen et al. 2000; Dragon et al. 2000; Pogacic et al. 2000; Wang and Meier 2004; Autexier and Lue 2006). Despite the fact that telomerase RNA stably associates with the pseudouridine synthase component of H/ACA RNPs, there is no indication that telomerase functions in RNA pseudouridylation (Chen et al. 2000). A short sequence in the RNA provides the template for the reverse transcription of telomeric DNA repeats by TERT.

\section{Discovery of Novel H/ACA RNAs}

In recent years, large-scale "RNomic" cloning efforts and innovative computational approaches have led to the discovery of numerous H/ACA RNAs in a variety of eukaryotes and archaea (see, e.g., Brown et al. 2001; Hüttenhofer et al. 2001; Klein et al. 2002; Tang et al. 2002; Yuan et al. 2003; Kiss et al. 2004; Russell et al. 2004; Schattner et al. 2004; Liang et al. 2005; Torchet et al. 2005). The current catalog of H/ACA RNAs includes a remarkable number of "orphan" RNAs that do not exhibit recognizable complementarity to known targets (i.e., rRNAs and snRNAs). Some of the new RNAs appear to contain additional sequence elements (beyond canonical pseudouridylation guide RNA domains), suggesting that they may be involved in distinct specialized functions (like telomerase RNA). One novel trypanosomal H/ACA RNA has been found to guide pseudouridylation of the spliced leader RNA that is added in trans to mRNAs in these organisms (Uliel et al. 2004). This is the first known instance of mRNAs harboring pseudouridine; however, it is probable that the role of this pseudouridine relates to the function of the spliced leader RNP (which shares features with snRNPs), rather than expression of the mRNA product.

\section{ANATOMY OF THE H/ACA RNAS}

The basic unit of the H/ACA RNAs is an imperfect hairpin structure with a short single-stranded tail that harbors the signature ACA sequence element (box ACA) or the variant ANANNA (box H) (Fig. 2) (Balakin et al. 1996; Ganot et al. 1997a,b). Each hairpin unit contains an internal loop flanked by upper and lower stems. The two halves of the loop typically bear short antisense elements that form a bipartite target recognition site (pseudouridylation pocket). Substrate sequences flanking the modification site are bound by the antisense elements, and the target uridine and an adjacent nucleotide are left unpaired. The distance ( $\sim 15$ nucleotides) between box ACA (or box $\mathrm{H}$ ) and the target uridine is conserved (Ganot et al. 1997a; Ni et al. 1997). The molecular basis for the " $n+15$ " spacing rule has been proposed to reflect the binding properties of the pseudouridine synthase that recognizes both the ACA element and the target uridine (Baker et al. 2005).

A common feature of archaeal H/ACA RNAs is a kinkturn (k-turn) motif located at the junction of the upper stem and apical loop. k-turns exist in a variety of RNAs where they have been found to bind a series of related proteins that induce a severe bend or "kink" of about $80-120^{\circ}$ in the phosphodiester backbone of RNA helices (Klein et al. 2001). The k-turn motif found in the archaeal $\mathrm{H} / \mathrm{ACA}$ RNAs is a relaxed variant and is bound by L7Ae 


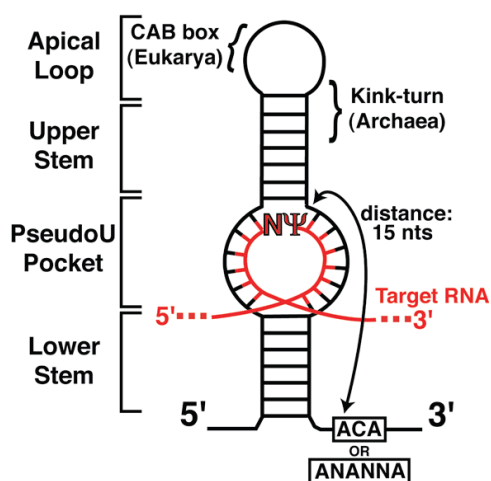

Figure 2. Anatomy of an H/ACA pseudouridylation guide RNA. The basic hairpin unit of the H/ACA RNA can be divided into an apical loop, upper stem, pseudouridylation pocket, and lower stem. In some eukaryotic H/ACA RNAs, a CAB box is found in the apical loop. A kink-turn motif is found in the upper stem of the archaeal H/ACA RNAs. The signature box $\mathrm{H}$ (ANANNA) or ACA motif is located immediately $3^{\prime}$ of the hairpin unit. Base-pairing of the target RNA (red) with antisense sequences in the pseudouridylation pocket positions the unpaired substrate uridine at the apex of the pocket. The approximately 15-nucleotide distance between the modified nucleotide $(\Psi)$ and box ACA (or $\mathrm{H}$ ) is conserved.

as detailed below (Hamma and Ferre-D'Amare 2004). There is currently no evidence for the existence of k-turns in eukaryotic H/ACA RNAs, and the eukaryotic homolog of L7Ae binds RNA without apparent sequence or structure specificity, at least in vitro (Henras et al. 2001; Wang and Meier 2004).

All H/ACA RNAs share basic architecture, but each functional class has unique features that enable distinct substrate interaction, protein binding, subcellular localization, and function (Fig. 3). The rRNA pseudouridylation guide RNAs of the nucleolus are the archetypes (and largely define the basic anatomy described above). Members of this largest H/ACA RNA family differ from one another in antisense element sequence (providing for recognition of distinct rRNA target sites) and can be composed of one, two, or three hairpin structures. All three configurations have been identified in archaea (Tang et al. 2002). Single-hairpin H/ACA RNAs exist in early diverging eukaryotes (trypanosmes) (Uliel et al. 2004), but double-hairpin molecules prevail in all other eukaryotic organisms.

The scaRNAs that guide pseudouridylation of snRNAs within the Cajal body in eukaryotes are distinguished from the snoRNAs by short sequence elements called CAB boxes (Cajal body box, consensus UGAG) found in the apical loop of each hairpin (Fig. 3). The CAB boxes are responsible for the Cajal body localization of this class of H/ACA RNAs (Richard et al. 2003). Otherwise, many snRNA pseudouridylation guide RNAs strongly resemble the canonical double-hairpin snoRNAs. In addition, however, interesting composite scaRNAs have been identified that consist of fusions of H/ACA RNAs with C/D RNAs (Jady and Kiss 2001; Darzacq et al. 2002; Kiss et al. 2002), a related but distinct family of RNAs that guide RNA ribose methylation (Terns and Terns 2002; Yu et al. 2005).
Telomerase RNA is a hybrid composed of an H/ACA domain and a specialized telomerase domain in vertebrates (Fig. 3) (Mitchell et al. 1999a; Chen et al. 2000). The 5' half of the RNA contains a large pseudoknot domain and a short template region required to synthesize telomeric repeats. The $3^{\prime}$ half is a modified double-hairpin H/ACA RNA. The H/ACA domain of vertebrate telomerase RNA is essential for RNA stability, 3 '-end formation, retention, and trafficking in the nucleus, as well as the function of the enzyme (Mitchell et al. 1999a; Lukowiak et al. 2001; Fu and Collins 2003; Jady et al. 2004). Similar to the scaRNAs, telomerase RNA localizes to Cajal bodies via a single $\mathrm{CAB}$ box in the apical loop of the 3' hairpin (Jady et al. 2004; Zhu et al. 2004; Jady et al. 2006; Tomlinson et al. 2006). The $5^{\prime}$ hairpin participates in binding telomerase reverse transcriptase (Chen et al. 2000; Mitchell and Collins 2000).

Finally, the small set of H/ACA RNAs that function in rRNA processing (e.g., U17/snR30 and snR10) has unique structural features that greatly depart from those found in pseudouridylation guide RNAs (Fig. 3). $\mathrm{U} 17 / \mathrm{snR} 30$ is the only H/ACA RNA whose sequence is conserved among diverse eukaryotes, and two conserved antisense sequence elements that are essential for pre-18S rRNA cleavages have been identified (Morrissey and Tollervey 1993). These elements are located in the 3' hairpin on opposite strands of the equivalent of the pseudouridine pocket (Cervelli et al. 2002; Atzorn et al. 2004; Eliceiri 2006).

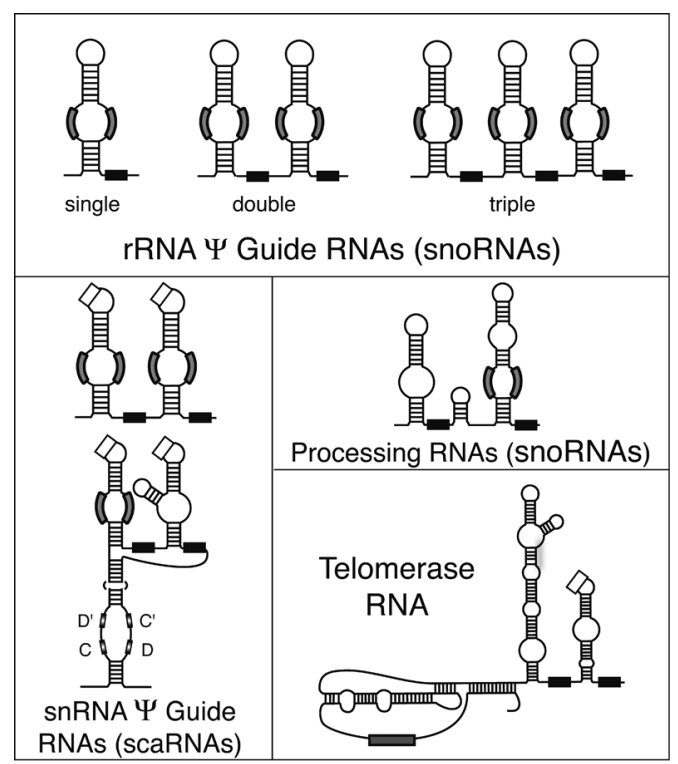

Figure 3. Structural diversity of H/ACA RNAs. H/ACA RNAs that guide pseudouridylation of rRNA (snoRNAs) are composed of one, two, or three tandemly arranged hairpin units each with an associated box H or ACA element (black boxes). The other classes of H/ACA RNAs harbor various specialized sequence elements. The snRNA guide RNAs (scaRNAs) can resemble double-hairpin H/ACA RNAs (upper) or be hybrid RNA containing both $\mathrm{H} / \mathrm{ACA}$ and $\mathrm{C} / \mathrm{D}$ elements (lower). scaRNAs and telomerase RNA contain CAB box elements (white boxes). Gray boxes indicate sequences involved in basepairing with RNA or DNA substrates. 


\section{CORE PROTEIN SUBUNITS OF H/ACA RNPS}

All H/ACA RNAs associate with a set of four highly conserved proteins and function as RNP complexes (Terns and Terns 2002; Meier 2005; Yu et al. 2005). The four core proteins include the enzyme required for pseudouridine formation and three smaller proteins: Garl (glycine-arginine-rich), Nop10 (nucleolar protein of $10 \mathrm{kD}$ ), and Nhp2 (nonhistone protein) or the archaeal homolog L7Ae. The pseudouridine synthase is variably called Cbf5 (yeast and archaea), dyskerin (human), or NAP57 (rat) and is related to the TruB family of pseudouridine synthases that modify tRNA (Koonin 1996). The identity and role of the proteins in pseudouridylation and rRNA processing were established in early genetic studies performed in yeast (Girard et al. 1992; Bousquet-Antonelli et al. 1997; Lafontaine et al. 1998; Watkins et al. 1998). These defining studies paved the path for the discovery and characterization of $\mathrm{H} / \mathrm{ACA}$ RNPs in other organisms.

\section{ROLE OF H/ACA RNPS IN DYSKERATOSIS CONGENITA}

Mutations in components of H/ACA RNPs are responsible for a serious inherited disease termed dyskeratosis congenita (DC). DC patients suffer a variety of clinical symptoms (indicating involvement of several proliferating cell types) that range from skin depigmentation and nail dystrophies to life-threatening bone marrow failure, premature aging, and increased propensity for certain cancers (Meier 2003; Marrone et al. 2005; Mason et al. 2005). The X-linked form of the disease results from point mutations in the dyskerin gene that lead to singleamino-acid changes in the protein (Heiss et al. 1998). Studies employing DC patient cells and mouse models of DC found that dyskerin mutations lead to defects in rRNA modification and processing, and/or telomere shortening (depending on the mutation and system investigated) (Mitchell et al. 1999b; Mochizuki et al. 2004). However, in the case of the autosomal form of DC, it is more clear that the etiology is associated with loss of telomerase function, as the relevant mutations are found in the gene encoding telomerase RNA (Vulliamy et al. 2001; Chen and Greider 2004).

\section{ORGANIZATION AND FUNCTION OF THE CORE H/ACA RNP}

\section{Reconstitution of Archaeal Pseudouridylation Guide RNPs}

Functional H/ACA RNPs have recently been reconstituted from recombinant archaeal proteins and in vitro transcribed RNAs (Baker et al. 2005; Charpentier et al. 2005). The studies performed with these reconstituted systems have very significantly advanced our understanding of the assembly, organization, and function of the H/ACA RNPs. For example, this work established that the four core proteins (Cbf5, Gar1, L7Ae, and Nop10) and guide RNA are necessary and sufficient for efficient pseudouridylation in vitro - the first evidence that these four proteins are directly involved in the modification and that they comprise the complete set of proteins required for RNA-guided pseudouridylation. Thus, although other known pseudouridine synthases act as single-subunit enzymes to recognize substrate RNAs and modify target uridines (Ofengand et al. 2001), Cbf5 requires three protein cofactors and a guide RNA for rRNA modification.

These studies also provided substantial insight into the interactions that mediate the assembly and contribute to the functional organization of the H/ACA RNP (Fig. 4) (Baker et al. 2005; Charpentier et al. 2005). Two of the proteins, L7Ae and Cbf5, interact directly with the H/ACA guide RNA. As was established in other work, L7Ae binds the k-turn in the upper stem of archaeal H/ACA RNAs (Rozhdestvensky et al. 2003; Baker et al. 2005; Charpentier et al. 2005; Hamma et al. 2005). It is now clear that Cbf5 is the component that recognizes the signature sequence element box ACA. Interaction of Cbf5 also depends on the pseudouridylation pocket and apical loop of the H/ACA RNA (Baker et al. 2005). In addition, Cbf5 recruits the essential proteins Nop10 and Gar1 to the complex via independent protein-protein interactions with each. L7Ae does not interact with any of the other three core H/ACA RNP proteins in the absence of the guide RNA (Baker et al. 2005).

Studies with single- and double-hairpin H/ACA RNAs indicate that each hairpin nucleates the assembly of all four core H/ACA RNP proteins (Baker et al. 2005; Charpentier et al. 2005; Hamma et al. 2005). This observation is consistent with the earlier interpretation of electron microscopic images of purified yeast H/ACA RNP particles that suggested symmetric organization of core RNPs at each hairpin unit (Watkins et al. 1998).

Studies to address how the reconstituted archaeal H/ACA RNPs recognize target RNA have yielded somewhat unexpected results. Clearly, the guide RNA has a key role in this process, but simple base-pairing of the guide and substrate RNAs, although necessary, is apparently not sufficient for target interaction. Stable guide RNA/target RNA duplexes cannot be detected under the conditions that support H/ACA RNP function in vitro

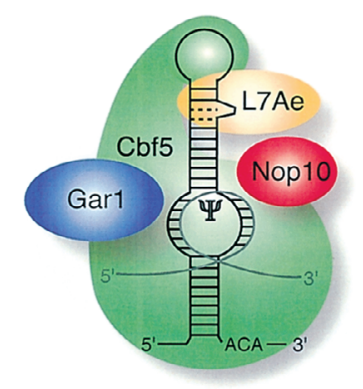

Figure 4. Organization of a pseudouridylation guide RNP. Recent studies with archaeal components indicate that L7Ae interacts with the k-turn of the H/ACA RNA; Cbf5 interacts with box ACA, the pseudouridylation pocket, and apical loop of the RNA; and Nop10 and Gar1 interact with Cbf5. (Adapted, with permission, from Baker et al. 2005.) 
(Charpentier et al. 2005). However, stable duplexes are detected in the presence of Nop10 and Cbf5, indicating a role for these two proteins in substrate recognition (Charpentier et al. 2005). Experiments to systematically assess whether L7Ae and Gar1 influence target RNA association have not yet been reported. Target recognition has also been observed to require a uridine in the substrate RNA (Charpentier et al. 2005). Since the target uridine is not predicted to be involved in base-pairing with the guide RNA, this observation also supports the role of one or more proteins in target RNA binding. One possibility is that protein binding is required to remodel the guide RNA to an open conformation, making the antisense elements of the loop available for base-pairing with target RNA. As a protein that recognizes both the pseudouridylation pocket and target uridine (Baker et al. 2005), Cbf5 is an obvious candidate for a remodeling function. Nop10 could influence target interaction directly or through its known interaction with Cbf5.

\section{Structural Characterization of H/ACA RNP Complexes}

Until very recently, the three-dimensional structures of all of the four core H/ACA RNP proteins were unknown; however, an abundance of new information is now available from a series of atomic-level structures of complexes of various components of the RNP (Fig. 5) (Hamma and Ferre-D'Amare 2004; Hamma et al. 2005; Manival et al. 2006; Rashid et al. 2006; Yu 2006). This work has provided not only the structures of the individual component proteins, but also insight into the molecular basis for key interactions and functions.
Cbf5 is the heart of the H/ACA RNP complex-binding the H/ACA guide RNA and recruiting the two essential protein cofactors Nop10 and Gar1, as well as catalyzing the isomerization of the target uridine. As expected on the basis of sequence homology, the overall structure of Cbf5 is similar to that of TruB, the bacterial pseudouridine synthase that catalyzes the highly conserved pseudouridylation of U55 in the T loop of tRNAs (Hoang and Ferre-D'Amare 2001). Like TruB, Cbf5 is composed of two major domains: an amino-terminal catalytic domain and a carboxy-terminal PUA domain (Fig. 5). The PUA (pseudouridine synthase and archaeosine transglycosylase) domain is common to a variety of RNA-binding proteins (Aravind and Koonin 1999) and, as described below, is likely to be involved in interaction of $\mathrm{Cbf5}$ with the H/ACA guide RNA. The catalytic domains of Cbf5 and TruB are virtually superimposable. Careful inspection reveals that all atoms important for catalysis, including a catalytic aspartate universal to all pseudouridine synthases, occupy nearly identical positions in Cbf5 and TruB. Thus, both enzymes likely use the same catalytic mechanism to isomerize uridine to pseudouridine (cleavage of the N-glycosidic bond, rotation of the uracil base, and reformation of a C-glycosidic bond).

At the same time, Cbf5 exhibits a few striking differences from TruB that can be correlated with known functional differences. For example, in place of the "thumbloop" domain of TruB that is involved in tRNA T-loop recognition and positioning of the target uridine in the active site cleft, Cbf5 has a unique structural element, the $\beta 7 / \beta 10$ hairpin loop. This loop arrives at a similar spatial location in the active site and likely has a role in recognition of the guide RNA/rRNA duplex. Another significant

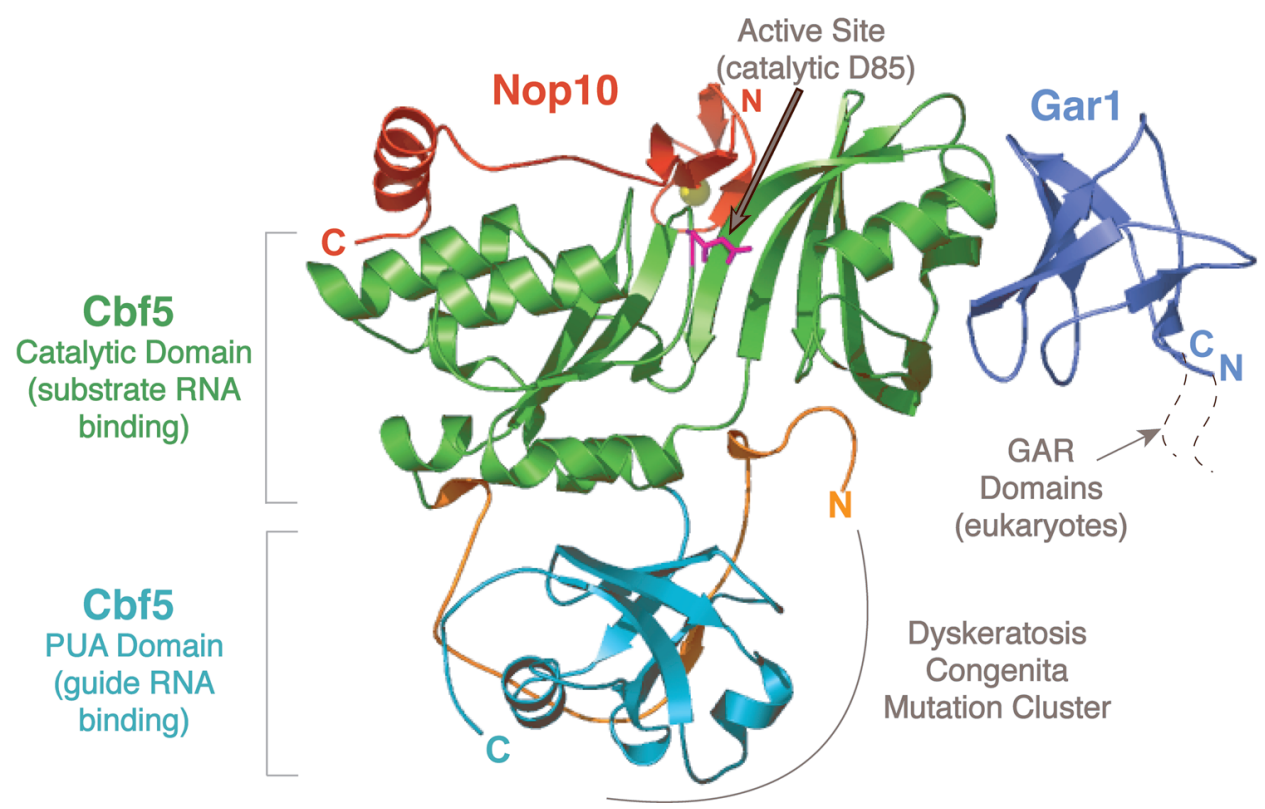

Figure 5. Structure of a heterotrimeric complex of Cbf5, Gar1, and Nop10. The pseudouridine synthase Cbf5 consists of two major domains: the catalytic domain (green) that contains the active site (D85), and a PUA domain (cyan). A long amino-terminal extension (gold) wraps around the PUA domain. Nop10 (red) and Gar1 (blue) interact on opposite sides of the active site of Cbf5. Modeling indicates that the mutations that cause dyskeratosis congenita cluster to a face of the PUA domain. (Adapted, with permission, from Rashid et al. 2006 [@ Elsevier].) 
distinction is the longer amino-terminal extension present in Cbf5. The amino terminus of Cbf5 encircles the carboxyterminal PUA domain, thereby expanding and constraining the PUA domain relative to that of TruB. It is also noteworthy that the overall fold of the PUA domain of Cbf5 is more similar to that of the PUA domain of archaeosine transglycosylase than TruB. Archaeosine transglycosylase catalyzes the first step in an archaea-specific, tRNA modification and interacts specifically with the acceptor stem and 3' CCA of the tRNA. It is tempting to speculate that the PUA domain of Cbf5 interacts with the lower stem and box ACA of the guide RNA in an analogous fashion; however, this is not currently known. Two patches enriched in basic residues flanking the active site and numerous residues distributed across both the catalytic and PUA domains are likely involved in RNA interaction (Hamma et al. 2005; Manival et al. 2006; Rashid et al. 2006).

Information on the precise binding sites of both Nop10 and Gar1 is available from the trimeric Cbf5/Nop10/Gar1 (Rashid et al. 2006) and dimeric Cbf5/Nop10 (Hamma et al. 2005; Manival et al. 2006) structures that have been solved (Fig. 5). As predicted from biochemical studies (Baker et al. 2005), Nop10 and Gar1 bind to distinct sites on Cbf5 (Rashid et al. 2006). The proteins interact with the catalytic domain of Cbf5 on opposite sides of the active site, suggesting that they function in catalytic activation of Cbf5 and/or interaction with the guide RNA/target RNA. The residues involved in the interactions of Nop10 and Gar1 with Cbf5 are generally conserved, indicating that assembly will be similar in archaea and eukaryotes.

Nop10 appears to be intrinsically unstructured, but is well ordered when bound to Cbf5. Nop10 consists of an amino-terminal zinc ribbon domain (in which a single zinc molecule is coordinated by four conserved cysteine residues) connected to a carboxy-terminal $\alpha$-helix by a short linker region (Hamma et al. 2005; Manival et al. 2006; Rashid et al. 2006). Each of these three domains makes extensive contact with Cbf5. The amino-terminal zinc-binding domain of Nop10 is not conserved in eukaryotes, and mutations predicted to disrupt zinc binding do not appreciably affect Nop10 function in vitro (Charpentier et al. 2005). Nop10 binds adjacent to the active site of Cbf5 and interacts with critical residues in the conserved pseudouridine synthase motif I, consistent with a role in catalytic activation. The binding of Nop10 to Cbf5 enhances the positive surface potential of the complex by shielding electronegative charges of Cbf5 and by contributing electropositive charges, which could be important in RNA interaction.

Gar1 forms a six- $\beta$-barrel structure and binds Cbf5 on the opposite side of the active site from Nop10 (Rashid et al. 2006). The binding of Gar1 to Cbf5 appears to influence formation of the $\beta 7 / \beta 10$ hairpin loop that is thought to be important in substrate RNA recognition within the active site of Cbf5 (discussed above). This loop is disordered in Cbf5 in the absence of Gar1 (Hamma et al. 2005).

As discussed above, L7Ae does not interact with the other H/ACA RNP proteins in the absence of the guide RNA (Baker et al. 2005). However, the details of the interaction between the L7Ae and an RNA k-turn have been captured in a co-crystal structure (Hamma and FerreD'Amare 2004). As has been found for other k-turn binding proteins, L7Ae induces a dramatic, approximately $120^{\circ}$ bend in the phosphodiester backbone of the RNA and flips out a nucleotide. This L7Ae-induced kink in the guide RNA presumably influences other regions of the guide RNA (e.g., pseudouridylation pocket) to positively affect catalytic activity.

\section{Eukaryotic Pseudouridylation Guide H/ACA RNPs}

The organization of H/ACA RNPs has also been investigated in eukaryotes, and the available evidence indicates that the architecture of the pseudouridylation guide RNPs is essentially similar in archaea and eukaryotes. For example, the mammalian Cbf5 homolog (dyskerin/ Nap57) also interacts with both Nop10 and Gar1 in the absence of guide RNAs (Wang and Meier 2004). Moreover, in yeast, Cbf5/Nop10/Gar1complexes were found to assemble in vivo in the absence of the L7Ae homolog (Nhp2p) and H/ACA RNAs (Henras et al. 2004).

One apparent difference in the eukaryotic and archaeal core H/ACA RNPs is in the L7Ae homologs (L7Ae in archaea and Nhp2 in eukaryotes). L7Ae interacts directly with the k-turn motif in archaeal H/ACA RNAs. However, eukaryotic H/ACA RNAs do not possess recognizable k-turns, and although Nhp2 exhibits nonspecific RNA-binding properties, it appears to be recruited to the complex via interaction with a complex of $\mathrm{Cbf} 5$ and Nop10 (Henras et al. 2001; Wang and Meier 2004). Nonetheless, it is quite possible that L7Ae and Nhp2 end up in similar spatial locations in the assembled RNPs and perform similar roles.

\section{ASSEMBLY AND TRAFFICKING PATHWAYS IN EUKARYOTES}

H/ACA RNP assembly and function involve dynamic and complex cellular trafficking of components in eukaryotic cells (Fig. 6). Current evidence indicates that nascent H/ACA RNAs are packaged into stable, but perhaps inactive, RNPs cotranscriptionally. It appears that the H/ACA RNP proteins are targeted to Cajal bodies for further maturation and then sent on to sites of function (i.e., nucleoli, Cajal bodies, or telomeres). These steps in assembly and trafficking appear to involve dynamic associations with non-H/ACA RNP proteins.

\section{RNP Assembly at the Site of Transcription}

Recent work in both yeast and mammalian systems indicates that RNP biogenesis begins on nascent H/ACA RNA proteins with cotranscriptional recruitment of three of the four core H/ACA RNP proteins, namely, Cbf5, Nop10, and Nhp2 (L7Ae homolog), and an assembly factor called Naf1 (Ballarino et al. 2005; Yang et al. 2005; Darzacq et al. 2006; Hoareau-Aveilla et al. 2006; Richard et al. 2006; Richard and Kiss 2006). Nafl appears to associate with assembling H/ACA complexes as a surrogate for Garl that is replaced during maturation of the RNP. 


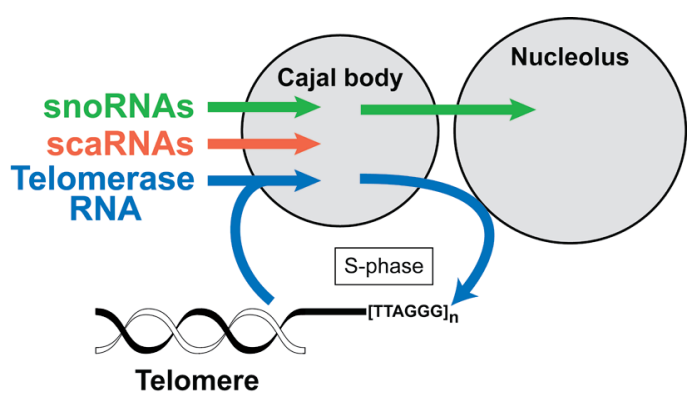

Figure 6. Intracellular trafficking of H/ACA RNAs. The major classes of H/ACA RNAs all appear to be initially targeted to Cajal bodies. scaRNAs are retained and function in Cajal bodies. snoRNAs quickly move on to nucleoli. During S phase, Cajal bodies containing telomerase RNA move to the nucleolar periphery and then appear to deliver the RNA to telomeres.

Naf1 and the core H/ACA proteins other than Gar1 are found at H/ACA genes in chromatin immunoprecipitations and a clever cell-based assay (Ballarino et al. 2005; Yang et al. 2005; Darzacq et al. 2006). Nafl can also be found associated with the H/ACA RNPs (snoRNPs, scaRNPs, and telomerase) (Dez et al. 2002; Fatica et al. 2002; Yang et al. 2002; Hoareau-Aveilla et al. 2006). The association is with free snoRNP fractions (where immature snoRNPs would be expected) rather than snoRNPs associated with ribosome components (i.e., engaged in function) (Dez et al. 2002). In addition, the protein is not found at known sites of mature H/ACA RNP function (such as nucleoli and Cajal bodies) (Dez et al. 2002; Yang et al. 2002; Darzacq et al. 2006; Hoareau-Aveilla et al. 2006). Naf1 is essential for the accumulation of all classes of H/ACA RNAs (snoRNAs, scaRNAs, and telomerase RNA) (Dez et al. 2002; Fatica et al. 2002; Yang et al. 2002; Darzacq et al. 2006; Hoareau-Aveilla et al. 2006).

Evidence indicates that Naf1 and Garl bind to a common site on Cbf5 in a mutually exclusive manner. The proteins share a region of protein homology (Fatica et al. 2002), and the recent structure of the archaeal Cbf5/ Gar1/Nop10 complex (Rashid et al. 2006) revealed that it is the homologous region of Gar1 that interacts with Cbf5. In vitro binding assays indicate that interaction of the two proteins with Cbf5 is mutually exclusive (Darzacq et al. 2006). The exchange of Nafl for Garl may mediate the controlled transition to an active H/ACA RNP.

\section{RNP Maturation at Cajal Bodies}

As indicated above, newly assembled H/ACA RNPs may not be functional. Moreover, there is evidence that all classes of H/ACA RNAs are rapidly targeted to Cajal bodies soon after synthesis (Fig. 6). Cajal bodies are intranuclear structures that house machinery which carries out posttranscriptional RNA alterations and assembly of RNA-protein complexes (Gall 2000; Cioce and Lamond 2005; Matera and Shpargel 2006). Gar1, but not Naf1, has been detected in Cajal bodies, suggesting that this may be the site of Naf1 exchange and Gar1 incorporation into maturing H/ACA RNPs (Pogacic et al. 2000).
Several observations suggest that the survival of motor neurons (SMN) complex may function in the incorporation of Gar1 into H/ACA RNPs and other aspects of complex maturation. The SMN complex is a known snRNP assembly factor (Terns and Terns 2001; Meister et al. 2002; Gubitz et al. 2004) and is concentrated in Cajal bodies (Matera and Frey 1998). In addition, the SMN protein interacts with Garl both in vivo and in vitro, and via the same domains that mediate binding and assembly of snRNPs (Pellizzoni et al. 2001; Whitehead et al. 2002). SMN has also been independently linked with telomerase by the observation that SMN antibodies can immunoprecipitate telomerase complexes (Bachand et al. 2002). Finally, the recent discovery that H/ACA scaRNAs and telomerase RNA also associate with a subset of Sm proteins, the snRNP components that interact with SMN, suggests further involvement of SMN in the assembly of these RNPs (Fu and Collins 2006).

Additional proteins implicated in the early steps of H/ACA RNP biogenesis or trafficking including Shq1, Nopp140, and two putative RNA or DNA helicases called RVB1/RVB2 (also known as TIP49a/b or p50/p55) (King et al. 2001; Dez et al. 2002; Fatica et al. 2002; Wang et al. 2002; Yang et al. 2002). The available evidence indicates that these proteins are required for H/ACA RNA accumulation but are not stable components of mature H/ACA RNPs.

\section{Delivery to Functional Destinations}

In the end, mechanisms must exist to ensure that a given H/ACA RNP reaches its site of action, which may be the nucleolus (snoRNPs), Cajal body (scaRNPs), or telomere (telomerase) (Fig. 6). cis-Acting sequences important for the ultimate subcellular targeting of some H/ACA RNAs have been identified.

The discrete RNA elements that mediate nucleolar targeting of H/ACA snoRNAs were identified by examining the localization patterns of large panels of mutants injected in Xenopus oocytes (Lange et al. 1999; Narayanan et al. 1999; Ruhl et al. 2000). The critical nucleolar localization sequences include box $\mathrm{H}$, box ACA, and the stem that tethers the two elements together (Narayanan et al. 1999; Lukowiak et al. 2001). These studies also demonstrated that the ability of H/ACA RNAs to base-pair with target RNAs is not critical for localization to nucleoli (Lange et al. 1999; Narayanan et al. 1999).

H/ACA snoRNAs rapidly traverse Cajal bodies en route to nucleoli, but the scaRNAs and telomerase RNA remain associated with Cajal bodies (but see more on telomerase RNA trafficking below). Cajal body localization of the scaRNAs and telomerase RNA relies on one or two copies of the $\mathrm{CAB}$ (Cajal body) box found in the apical loop(s) of these H/ACA RNAs (Fig. 3) (Richard et al. 2003). Both the CAB boxes and H/ACA domain (i.e., nucleolar targeting information) are required for proper Cajal body localization (Richard et al. 2003). Mutation of the $\mathrm{CAB}$ boxes results in loss of Cajal body localization and appearance of the RNAs in nucleoli, indicating that the $\mathrm{CAB}$ signal dominates the nucleolar targeting signal 
in these RNAs (Richard et al. 2003; Jady et al. 2004).

Recent work indicates that the association of a set of Sm proteins with scaRNAs and telomerase RNA depends on the CAB box (Fu and Collins 2006). It is not known whether the association is direct. Curiously, mutations of the CAB box of telomerase RNA that disrupt the association of the Sm proteins (and presumably Cajal body localization) do not appear to significantly affect the biogenesis, stability, or function of telomerase $(\mathrm{Fu}$ and Collins 2006). In addition, the Ku70/80 proteins (components of the nonhomologous end-joining DNA-repair complexes) associate both in vitro and in vivo with a $3^{\prime}$ fragment of telomerase RNA that includes the CAB box (Ting et al. 2005).

The activity of telomerase is restricted to S phase (Ten Hagen et al. 1990; Wright et al. 1999), and its trafficking (as well as that of its partner TERT) appears to be regulated as a function of the cell cycle (Jady et al. 2006; Tomlinson et al. 2006). Throughout most of the cell cycle, telomerase RNA is detected in Cajal bodies. However, during $\mathrm{S}$ phase, Cajal bodies containing the RNA mobilize to the periphery of nucleoli (early S) and then the RNA moves into foci adjacent to the Cajal bodies and finally to telomeres (peaking at mid S phase) (Jady et al. 2006; Tomlinson et al. 2006). It has been proposed that Cajal bodies directly deliver telomerase RNA to telomeres during $S$ phase (Jady et al. 2006). Endogenous TERT protein is found in unidentified foci during most of the cell cycle and appears within nucleoli in early $S$ phase and, like telomerase RNA, at Cajal-body-associated foci and telomeres in mid S phase (Tomlinson et al. 2006). The regulated intracellular trafficking of the key components of telomerase may be a mechanism for the control of telomerase activity.

\section{CONCLUSIONS}

The H/ACA RNPs are a diverse and abundant family of trans-acting RNA-protein complexes that eukaryotic cells depend on for multiple essential functions. H/ACA RNPs have apparently been present in cells for more than 2-3 billion years. The ancestral function appears to have been pseudouridylation of rRNA and ribosome biogenesis, but numerous distinct H/ACA RNA species have evolved to expand the substrates and functions of the H/ACA RNPs.

The focus of this review has been the impressive progress made in understanding the biogenesis, structure, and function of the H/ACA RNPs during the last decade. However, aspects of the expression of the H/ACA RNAs are also noteworthy. H/ACA RNAs were among the first gene products recognized to arise from introns. The vast majority of vertebrate H/ACA RNAs are encoded within introns of protein-coding pre-mRNAs and are processed out following splicing (Filipowicz and Pogacic 2002; Kiss 2002; Terns and Terns 2002). Moreover, the discovery of brain-specific mammalian H/ACA RNAs (Cavaille et al. 2000) reveals that the H/ACA RNPs likely participate in tissue-specific functions that are not yet understood.

The large number of orphan H/ACA RNAs also pre- dicts new substrates and functions to be discovered. Approximately $20 \%$ of the human H/ACA RNAs do not match known targets (Lestrade and Weber 2006). It has long been known that snoRNAs themselves contain pseudouridine residues, and it seems likely that $\mathrm{H} / \mathrm{ACA}$ guide RNAs will be identified for these modifications, and perhaps also for modification of other noncoding RNAs (e.g., telomerase RNA and microRNAs).

With so much more to learn, it seems likely that the H/ACA RNPs will continue to be a lead system for understanding the biology of noncoding RNA-protein complexes for years to come.

\section{Note Added in Proof}

We want to alert the reader to an article of interest published after the writing of this review. Li and Ye (2006) have now described the structure of the H/ACA RNP including a guide RNA as well as all four essential proteins. The results support many of the hypotheses developed from the previous studies that were described above.

\section{ACKNOWLEDGMENTS}

We thank Caryn Hale and Connor Hale for assistance with figure preparation, and members of the Terns lab (past and present) who have contributed to our research on H/ACA RNPs, especially Dan Baker, Osama Youssef, Caryn Hale, Sarah Marshburn, Rebecca Tomlinson, ZhuHong Li, Tania Zeigler, Emem Adolf, Eladio Abreu, Tim Supakorndej, Natasha Starostina, Michael Chastkofsky, David Dy, Yusheng Zhu, Sarah Whitehead-Finch, Aarthi Narayanan, and Andrew Lukowiak. We express our sincere gratitude to Michael Adams (Department of Biochemistry and Molecular Biology, University of Georgia) for his crucial support of our endeavors to understand the archaeal H/ACA RNPs. Finally, we have enjoyed fruitful collaborations on this topic with Hong Li, Tamas Kiss, Sean Eddy, Chris Counter, Yi-Tao Yu, Joan Steitz, Louis Droogmans, and Henri Grosjean. This work was supported by National Institutes of Health grants RO1 GM54682 and RO1 CA104676 to M. Terns and R. Terns.

\section{REFERENCES}

Aravind L. and Koonin E.V. 1999. Novel predicted RNA-binding domains associated with the translation machinery. $J$. Mol. Evol. 48: 291

Atzorn V., Fragapane P., and Kiss T. 2004. U17/snR30 is a ubiquitous snoRNA with two conserved sequence motifs essential for 18S rRNA production. Mol. Cell. Biol. 24: 1769.

Autexier C. and Lue N.F. 2006. The structure and function of telomerase reverse transcriptase. Annu. Rev. Biochem. 75: 493.

Bachand F., Boisvert F.M., Cote J., Richard S., and Autexier C. 2002. The product of the survival of motor neuron (SMN) gene is a human telomerase-associated protein. Mol. Biol. Cell 13: 3192.

Bachellerie J.P., Michot B., Nicoloso M., Balakin A., Ni J., and Fournier M.J. 1995. Antisense snoRNAs: A family of nucleolar RNAs with long complementarities to rRNA. Trends Biochem. Sci. 20: 261.

Baker D.L., Youssef O.A., Chastkofsky M.I., Dy D.A., Terns R.M., and Terns M.P. 2005. RNA-guided RNA modification: 
Functional organization of the archaeal H/ACA RNP. Genes Dev. 19: 1238 .

Balakin A.G., Smith L., and Fournier M.J. 1996. The RNA world of the nucleolus: Two major families of small RNAs defined by different box elements with related functions. Cell 86: 823 .

Ballarino M., Morlando M., Pagano F., Fatica A., and Bozzoni I. 2005. The cotranscriptional assembly of snoRNPs controls the biosynthesis of H/ACA snoRNAs in Saccharomyces cerevisiae. Mol. Cell. Biol. 25: 5396.

Bousquet-Antonelli C., Henry Y., G'Elugne J.P., CaizerguesFerrer M., and Kiss T. 1997. A small nucleolar RNP protein is required for pseudouridylation of eukaryotic ribosomal RNAs EMBO J. 16: 4770 .

Brown J.W., Clark G.P., Leader D.J., Simpson C.G., and Lowe T. 2001. Multiple snoRNA gene clusters from Arabidopsis. RNA 7: 1817.

Brown J.W., Echeverria M., Qu L.H., Lowe T.M., Bachellerie J.P., Hüttenhofer A., Kastenmayer J.P., Green P.J., Shaw P., and Marshall D.F. 2003. Plant snoRNA database. Nucleic Acids Res. 31: 432.

Cavaille J., Buiting K., Kiefmann M., Lalande M., Brannan C.I., Horsthemke B., Bachellerie J.P., Brosius J., and Hüttenhofer A. 2000. Identification of brain-specific and imprinted small nucleolar RNA genes exhibiting an unusual genomic organization. Proc. Natl. Acad. Sci. 97: 14311

Cervelli M., Cecconi F., Giorgi M., Annesi F., Oliverio M., and Mariottini P. 2002. Comparative structure analysis of vertebrate U17 small nucleolar RNA (snoRNA). J. Mol. Evol. 54: 166.

Charpentier B., Muller S., and Branlant C. 2005. Reconstitution of archaeal H/ACA small ribonucleoprotein complexes active in pseudouridylation. Nucleic Acids Res. 33: 3133.

Chen J.L. and Greider C.W. 2004. Telomerase RNA structure and function: Implications for dyskeratosis congenita. Trends Biochem Sci. 29: 183

Chen J.L., Blasco M.A., and Greider C.W. 2000. Secondary structure of vertebrate telomerase RNA. Cell 100: 503.

Cioce M. and Lamond A.I. 2005. Cajal bodies: A long history of discovery. Annu. Rev. Cell Dev. Biol. 21: 105.

Darzacq X., Jady B.E., Verheggen C., Kiss A.M., Bertrand E., and Kiss T. 2002. Cajal body-specific small nuclear RNAs: A novel class of 2'-O- methylation and pseudouridylation guide RNAs. EMBO J. 21: 2746.

Darzacq X., Kittur N., Roy S., Shav-Tal Y., Singer R.H., and Meier U.T. 2006. Stepwise RNP assembly at the site of H/ACA RNA transcription in human cells. J. Cell Biol. 173: 207.

de Lange T. 2005. Shelterin: The protein complex that shapes and safeguards human telomeres. Genes Dev. 19: 2100.

Decatur W.A. and Fournier M.J. 2003. RNA-guided nucleotide modification of ribosomal and other RNAs. J. Biol. Chem. 278: 695 .

Dez C., Noaillac-Depeyre J., Caizergues-Ferrer M., and Henry Y. 2002. Naflp, an essential nucleoplasmic factor specifically required for accumulation of box H/ACA small nucleolar RNPs Mol. Cell. Biol. 22: 7053

Dragon F., Pogacic V., and Filipowicz W. 2000. In vitro assembly of human H/ACA small nucleolar RNPs reveals unique features of U17 and telomerase RNAs. Mol. Cell. Biol. 20: 3037.

Eliceiri G.L. 2006. The vertebrate E1/U17 small nucleolar ribonucleoprotein particle. J. Cell. Biochem. 98: 486.

Fatica A., Dlakic M., and Tollervey D. 2002. Naflp is a box H/ACA snoRNP assembly factor. RNA 8: 1502 .

Filipowicz W. and Pogacic V. 2002. Biogenesis of small nucleolar ribonucleoproteins. Curr. Opin. Cell Biol. 14: 319.

$\mathrm{Fu}$ D. and Collins K. 2003. Distinct biogenesis pathways for human telomerase RNA and H/ACA small nucleolar RNAs. Mol. Cell 11: 1361.

. 2006. Human telomerase and Cajal body ribonucleoproteins share a unique specificity of $\mathrm{Sm}$ protein association. Genes Dev. 20: 531

Gall J.G. 2000. Cajal bodies: The first 100 years. Annu. Rev. Cell Dev. Biol. 16: 273.
Ganot P., Bortolin M.L., and Kiss T. 1997a. Site-specific pseudouridine formation in preribosomal RNA is guided by small nucleolar RNAs. Cell 89: 799.

Ganot P., Caizergues-Ferrer M., and Kiss T. 1997b. The family of box ACA small nucleolar RNAs is defined by an evolutionarily conserved secondary structure and ubiquitous sequence elements essential for RNA accumulation. Genes Dev. 11: 941 .

Girard J.P., Lehtonen H., Caizergues-Ferrer M., Amalric F., Tollervey D., and Lapeyre B. 1992. GAR1 is an essential small nucleolar RNP protein required for pre-rRNA processing in yeast. $E M B O J .11: 673$

Greider C.W. and Blackburn E.H. 1985. Identification of a specific telomere terminal transferase activity in Tetrahymena extracts. Cell 43: 405.

Gubitz A.K., Feng W., and Dreyfuss G. 2004. The SMN complex. Exp. Cell Res. 296: 51.

Hamma T. and Ferre-D'Amare A.R. 2004. Structure of protein L7Ae bound to a K-turn derived from an archaeal box H/ACA sRNA at $1.8 \AA$ resolution. Structure 12: 893.

Hamma T., Reichow S.L., Varani G., and Ferre-D’Amare A.R. 2005. The Cbf5-Nop10 complex is a molecular bracket that organizes box H/ACA RNPs. Nat. Struct. Mol. Biol. 12: 1101.

Heiss N.S., Knight S.W., Vulliamy T.J., Klauck S.M., Wiemann S., Mason P.J., Poustka A., and Dokal I. 1998. X-linked dyskeratosis congenita is caused by mutations in a highly conserved gene with putative nucleolar functions. Nat. Genet. 19: 32.

Henras A.K., Capeyrou R., Henry Y., and Caizergues-Ferrer M. 2004. Cbf5p, the putative pseudouridine synthase of H/ACAtype snoRNPs, can form a complex with Garlp and Nop10p in absence of Nhp2p and box H/ACA snoRNAs. RNA 10: 1704.

Henras A., Dez C., Noaillac-Depeyre J., Henry Y., and Caizergues-Ferrer M. 2001. Accumulation of H/ACA snoRNPs depends on the integrity of the conserved central domain of the RNA-binding protein Nhp2p. Nucleic Acids Res. 29: 2733.

Hoang C. and Ferre-D'Amare A.R. 2001. Cocrystal structure of a tRNA Psi55 pseudouridine synthase: Nucleotide flipping by an RNA-modifying enzyme. Cell 107: 929.

Hoareau-Aveilla C., Bonoli M., Caizergues-Ferrer M., and Henry Y. 2006. hNafl is required for accumulation of human box H/ACA snoRNPs, scaRNPs, and telomerase. RNA 12: 832.

Hug N. and Lingner J. 2006. Telomere length homeostasis. Chromosoma 115: 413.

Hüttenhofer A., Kiefmann M., Meier-Ewert S., O'Brien J., Lehrach H., Bachellerie J.P., and Brosius J. 2001. RNomics: An experimental approach that identifies 201 candidates for novel, small, non-messenger RNAs in mouse. EMBO J. 20: 2943.

Jady B.E. and Kiss T. 2001. A small nucleolar guide RNA functions both in $2^{\prime}$-O-ribose methylation and pseudouridylation of the U5 spliceosomal RNA. EMBOJ. 20: 541.

Jady B.E., Bertrand E., and Kiss T. 2004. Human telomerase RNA and box H/ACA scaRNAs share a common Cajal bodyspecific localization signal. J. Cell Biol. 164: 647.

Jady B.E., Richard P., Bertrand E., and Kiss T. 2006. Cell cycledependent recruitment of telomerase RNA and Cajal bodies to human telomeres. Mol. Biol. Cell. 17: 944.

King T.H., Liu B., McCully R.R., and Fournier M.J. 2003. Ribosome structure and activity are altered in cells lacking snoRNPs that form pseudouridines in the peptidyl transferase center. Mol. Cell 11: 425.

King T.H., Decatur W.A., Bertrand E., Maxwell E.S., and Fournier M.J. 2001. A well-connected and conserved nucleoplasmic helicase is required for production of box C/D and H/ACA snoRNAs and localization of snoRNP proteins. Mol. Cell. Biol. 21: 7731 .

Kiss A.M., Jady B.E., Bertrand E., and Kiss T. 2004. Human box H/ACA pseudouridylation guide RNA machinery. Mol. Cell. Biol. 24: 5797.

Kiss A.M., Jady B.E., Darzacq X., Verheggen C., Bertrand E., and Kiss T. 2002. A Cajal body-specific pseudouridylation guide RNA is composed of two box H/ACA snoRNA-like domains. Nucleic Acids Res. 30: 4643. 
Kiss T. 2002. Small nucleolar RNAs: An abundant group of noncoding RNAs with diverse cellular functions. Cell 109: 145.

Klein D.J., Schmeing T.M., Moore P.B., and Steitz T.A. 2001. The kink-turn: A new RNA secondary structure motif. EMBO J. 20: 4214.

Klein R.J., Misulovin Z., and Eddy S.R. 2002. Noncoding RNA genes identified in AT-rich hyperthermophiles. Proc. Natl. Acad. Sci. 99: 7542.

Koonin E.V. 1996. Pseudouridine synthases: Four families of enzymes containing a putative uridine-binding motif also conserved in dUTPases and dCTP deaminases. Nucleic Acids Res. 24: 2411.

Lafontaine D.L., Bousquet-Antonelli C., Henry Y., CaizerguesFerrer M., and Tollervey D. 1998. The box H + ACA snoRNAs carry Cbf5p, the putative rRNA pseudouridine synthase. Genes Dev. 12: 527.

Lange T.S., Ezrokhi M., Amaldi F., and Gerbi S.A. 1999. Box H and box ACA are nucleolar localization elements of U17 small nucleolar RNA. Mol. Biol. Cell 10: 3877.

Lestrade L. and Weber M.J. 2006. snoRNA-LBME-db, a comprehensive database of human H/ACA and C/D box snoRNAs. Nucleic Acids Res. 34: D158.

Li L. and Ye K. 2006. Crystal structure of an H/ACA box ribonucleoprotein particle. Nature 443: 302.

Liang X.H., Uliel S., A. Hury, Barth S., Doniger T., Unger R., and Michaeli S. 2005. A genome-wide analysis of C/D and H/ACA-like small nucleolar RNAs in Trypanosoma brucei reveals a trypanosome-specific pattern of rRNA modification. RNA 11: 619 .

Lubben B., Fabrizio P., Kastner B., and Luhrmann R. 1995. Isolation and characterization of the small nucleolar ribonucleoprotein particle snR30 from Saccharomyces cerevisiae. $J$. Biol. Chem. 270: 11549.

Lukowiak A.A., Narayanan A., Li Z.H., Terns R.M., and Terns M.P. 2001. The snoRNA domain of vertebrate telomerase RNA functions to localize the RNA within the nucleus. RNA 7: 1833.

Maden B.E. 1990. The numerous modified nucleotides in eukaryotic ribosomal RNA. Prog. Nucleic Acid Res. Mol. Biol. 39: 241.

Manival X., Charron C., Fourmann J.B., Godard F., Charpentier B., and Branlant C. 2006. Crystal structure determination and site-directed mutagenesis of the Pyrococcus abyssi aCBF5aNOP10 complex reveal crucial roles of the C-terminal domains of both proteins in H/ACA sRNP activity. Nucleic Acids Res. 34: 826.

Marrone A., Walne A., and Dokal I. 2005. Dyskeratosis congenita: Telomerase, telomeres and anticipation. Curr. Opin. Genet. Dev. 15: 249.

Mason P.J., Wilson D.B., and Bessler M. 2005. Dyskeratosis congenita-A disease of dysfunctional telomere maintenance. Curr. Mol. Med. 5: 159.

Matera A.G. and Frey M.R. 1998. Coiled bodies and gems: Janus or gemini? Am. J. Hum. Genet. 63: 317.

Matera A.G. and Shpargel K.B. 2006. Pumping RNA: Nuclear bodybuilding along the RNP pipeline. Curr. Opin. Cell Biol. 18: 317.

Meier U.T. 2003. Dissecting dyskeratosis. Nat. Genet. 33: 116.

. 2005. The many facets of H/ACA ribonucleoproteins. Chromosoma 114: 1 .

Meister G., Eggert C., and Fischer U. 2002. SMN-mediated assembly of RNPs: A complex story. Trends Cell Biol. 12: 472.

Mishra R.K. and Eliceiri G.L. 1997. Three small nucleolar RNAs that are involved in ribosomal RNA precursor processing. Proc. Natl. Acad. Sci. 94: 4972.

Mitchell J.R. and Collins K. 2000. Human telomerase activation requires two independent interactions between telomerase RNA and telomerase reverse transcriptase. Mol. Cell 6: 361.

Mitchell J.R., Cheng J., and Collins K. 1999a. A box H/ACA small nucleolar RNA-like domain at the human telomerase RNA 3' end. Mol. Cell. Biol. 19: 567.

Mitchell J.R., E. Wood E., and Collins K. 1999b. A telomerase component is defective in the human disease dyskeratosis congenita. Nature 402: 551.
Mochizuki Y., He J., Kulkarni S., Bessler M., and Mason P.J. 2004. Mouse dyskerin mutations affect accumulation of telomerase RNA and small nucleolar RNA, telomerase activity, and ribosomal RNA processing. Proc. Natl. Acad. Sci. 101: 10756.

Morrissey J.P. and Tollervey D. 1993. Yeast snR30 is a small nucleolar RNA required for 18S rRNA synthesis. Mol. Cell. Biol. 13: 2469.

Narayanan A., Lukowiak A., Jady B.E., Dragon F., Kiss T., Terns R.M., and Terns M.P. 1999. Nucleolar localization signals of box H/ACA small nucleolar RNAs. EMBO J. 18: 5120.

Ni J., Tien A.L., and Fournier M.J. 1997. Small nucleolar RNAs direct site-specific synthesis of pseudouridine in ribosomal RNA. Cell 89: 565.

Ofengand J., Malhotra A., Remme J., Gutgsell N.S., Del Campo M., Jean-Charles S., Peil L., and Kaya Y. 2001. Pseudouridines and pseudouridine synthases of the ribosome. Cold Spring Harbor Symp. Quant. Biol. 66: 147.

Pellizzoni L., Baccon J., Charroux B., and Dreyfuss G. 2001. The survival of motor neurons (SMN) protein interacts with the snoRNP proteins fibrillarin and GAR1. Curr. Biol. 11: 1079.

Pogacic V., Dragon F., and Filipowicz W. 2000. Human H/ACA small nucleolar RNPs and telomerase share evolutionarily conserved proteins NHP2 and NOP10. Mol. Cell. Biol. 20: 9028.

Rashid R., Liang B., Baker D.L., Youssef O.A., He Y., Phipps K., Terns R.M., Terns M.P., and Li H. 2006. Crystal structure of a Cbf5-Nop10-Gar1 complex and implications in RNAguided pseudouridylation and dyskeratosis congenita. Mol. Cell 21: 249.

Richard P. and Kiss T. 2006. Integrating snoRNP assembly with mRNA biogenesis. EMBO Rep. 7: 590.

Richard P., Kiss A.M., Darzacq X., and Kiss T. 2006. Cotranscriptional recognition of human intronic box H/ACA snoRNAs occurs in a splicing-independent manner. Mol. Cell. Biol. 26: 2540.

Richard P., Darzacq X., Bertrand E., Jady B.E., Verheggen C., and Kiss T. 2003. A common sequence motif determines the Cajal body-specific localization of box H/ACA scaRNAs. EMBO J. 22: 4283 .

Rozhdestvensky T.S., Tang T.H., Tchirkova I.V., Brosius J., Bachellerie J.P., and Hüttenhofer A. 2003. Binding of L7Ae protein to the K-turn of archaeal snoRNAs: A shared RNA binding motif for C/D and H/ACA box snoRNAs in Archaea. Nucleic Acids Res. 31: 869.

Ruhl D.D., Pusateri M.E., and Eliceiri G.L. 2000. Multiple conserved segments of E1 small nucleolar RNA are involved in the formation of a ribonucleoprotein particle in frog oocytes. Biochem. J. 348: 517.

Russell A.G., Schnare M.N., and Gray M.W. 2004. Pseudouridine-guide RNAs and other Cbf5p-associated RNAs in Euglena gracilis. RNA 10: 1034 .

Schattner P., Decatur W.A., Davis C.A., Ares M., Jr., Fournier M.J., and Lowe T.M. 2004. Genome-wide searching for pseudouridylation guide snoRNAs: Analysis of the Saccharomyces cerevisiae genome. Nucleic Acids Res. 32: 4281.

Steitz J.A. and Tycowski K.T. 1995. Small RNA chaperones for ribosome biogenesis. Science 270: 1626.

Tang T.H., Bachellerie J.P., Rozhdestvensky T., Bortolin M.L., Huber H., Drungowski M., Elge T., Brosius J., and Hüttenhofer A. 2002. Identification of 86 candidates for small nonmessenger RNAs from the archaeon Archaeoglobus fulgidus. Proc. Natl. Acad. Sci. 99: 7536.

Ten Hagen K.G., Gilbert D.M., Willard H.F., and Cohen S.N. 1990. Replication timing of DNA sequences associated with human centromeres and telomeres. Mol. Cell. Biol. 10: 6348.

Terns M.P. and Terns R.M. 2001. Macromolecular complexes: SMN-The master assembler. Curr. Biol. 11: R862.

- 2002. Small nucleolar RNAs: Versatile trans-acting molecules of ancient evolutionary origin. Gene Expr. 10: 17.

Ting N.S., Yu Y., Pohorelic B., Lees-Miller S.P., and Beattie T.L. 2005. Human Ku70/80 interacts directly with hTR, the RNA component of human telomerase. Nucleic Acids Res. 33: 2090 . 


\section{H/ACA RNPS}

Tollervey D. 1987. A yeast small nuclear RNA is required for normal processing of pre-ribosomal RNA. EMBO J. 6: 4169.

Tomlinson R.L., Ziegler T.D., Supakorndej T., Terns R.M., and Terns M.P. 2006. Cell cycle-regulated trafficking of human telomerase to telomeres. Mol. Biol. Cell 17: 955.

Torchet C., Badis G., Devaux F., Costanzo G., Werner M., and Jacquier A. 2005. The complete set of H/ACA snoRNAs that guide rRNA pseudouridylations in Saccharomyces cerevisiae. RNA 11: 928.

Uliel S., Liang X.H., Unger R., and Michaeli S. 2004. Small nucleolar RNAs that guide modification in trypanosomatids: Repertoire, targets, genome organisation, and unique functions. Int. J. Parasitol. 34: 445.

Vulliamy T., Marrone A., Goldman F., Dearlove A., Bessler M., Mason P.J., and Dokal I. 2001. The RNA component of telomerase is mutated in autosomal dominant dyskeratosis congenita. Nature 413: 432.

Wang C. and Meier U.T. 2004. Architecture and assembly of mammalian H/ACA small nucleolar and telomerase ribonucleoproteins. EMBO J. 23: 1857.

Wang C., Query C.C., and Meier U.T. 2002. Immunopurified small nucleolar ribonucleoprotein particles pseudouridylate rRNA independently of their association with phosphorylated Nopp140. Mol. Cell. Biol. 22: 8457.

Watkins N.J., Gottschalk A., Neubauer G., Kastner B., Fabrizio P., Mann M., and Luhrmann R. 1998. Cbf5p, a potential pseudouridine synthase, and Nhp2p, a putative RNA-binding protein, are present together with Garlp in all $\mathrm{H} \mathrm{BOX} / \mathrm{ACA}$-motif snoRNPs and constitute a common bipartite structure. $R N A$ 4: 1549 .
Whitehead S.E., Jones K.W., Zhang X., Cheng X., Terns R.M., and Terns M.P. 2002. Determinants of the interaction of the spinal muscular atrophy disease protein SMN with the dimethylarginine-modified box H/ACA small nucleolar ribonucleoprotein GAR1. J. Biol. Chem. 277: 48087.

Wright W.E., Tesmer V.M., Liao M.L., and Shay J.W. 1999. Normal human telomeres are not late replicating. Exp. Cell Res. 251: 492.

Yang P.K., Rotondo G., Porras T., Legrain P., and Chanfreau G. 2002. The Shq1p.Naflp complex is required for box H/ACA small nucleolar ribonucleoprotein particle biogenesis. J. Biol. Chem. 277: 45235.

Yang P.K., Hoareau C., Froment C., Monsarrat B., Henry Y., and Chanfreau G. 2005. Cotranscriptional recruitment of the pseudouridylsynthetase Cbf5p and of the RNA binding protein Naflp during H/ACA snoRNP assembly. Mol. Cell. Biol. 25: 3295 .

Yu Y.T. 2006. The most complex pseudouridylase. Structure 14: 167

Yu Y.T., Terns R.M., and Terns M.P. 2005. Mechanisms and functions of RNA-guided RNA modification. Top. Curr. Genet. 12: 223

Yuan G., Klambt C., Bachellerie J.P., Brosius J., and Hüttenhofer A. 2003. RNomics in Drosophila melanogaster: Identification of 66 candidates for novel non-messenger RNAs. $\mathrm{Nu}$ cleic Acids Res. 31: 2495.

Zhu Y., Tomlinson R.L., Lukowiak A.A., Terns R.M., and Terns M.P. 2004. Telomerase RNA accumulates in Cajal bodies in human cancer cells. Mol. Biol. Cell 15: 81 . 


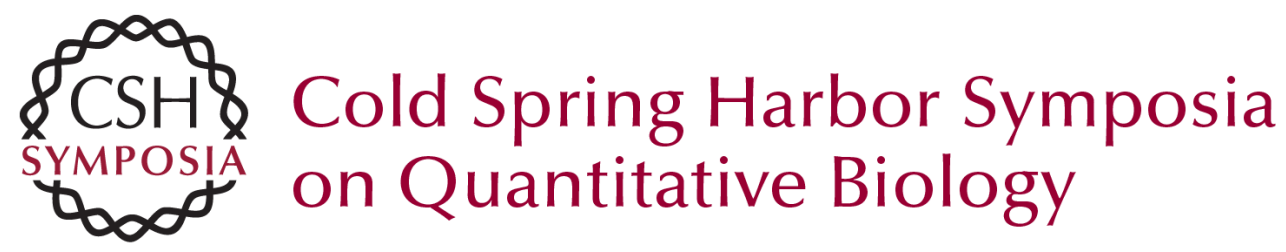

\section{Noncoding RNAs of the H/ACA Family}

M. TERNS and R. TERNS

Cold Spring Harb Symp Quant Biol 2006 71: 395-405

Access the most recent version at doi:10.1101/sqb.2006.71.034

References This article cites 111 articles, 52 of which can be accessed free at: http://symposium.cshlp.org/content/71/395.full.htmI\#ref-list-1

\section{License}

Email Alerting Receive free email alerts when new articles cite this article - sign up in Service the box at the top right corner of the article or click here. 